\title{
"OS CHARRUAS VIVEM" NOS GAÚCHOS: A VIDA SOCIAL DE UMA PESQUISA DE "RESGAIE" GENÉTICO DE UMA ETNIA INDÍGENA EXIINTA NO SUL DO BRASIL
}

\author{
Michael Kent \\ University of Manchester - Inglaterra
}

\section{Ricardo Ventura Santos}

\section{Escola Nacional de Saúde Pública/Fundação Oswaldo Cruz - Brasil}

Resumo: Este artigo explora a articulação entre uma pesquisa de ancestralidade genética e a construção social de identidades étnicas no Rio Grande do Sul. Isso é feito através da análise da vida social de um projeto de pesquisa conduzido por pesquisadores da Universidade Federal do Rio Grande do Sul (UFRGS). Tal investigação estabeleceu a continuidade genética entre a população Gaúcha contemporânea e os presumidamente extintos Charrua, uma etnia indígena que vivia na região do Pampa do estado. Ao longo do desenvolvimento do projeto de pesquisa, a ideia de continuidade genética passou por diferentes configurações, a depender de contextos específicos, sendo afirmada com diferentes níveis de certeza. A presente análise enfoca as

* Este texto é produto do projeto de pesquisa "Raça, Genômica e Mestiçagem na América Latina: Uma Abordagem Comparativa", sob a coordenação geral de Peter Wade (University of Manchester) e, no Brasil, de Ricardo Ventura Santos, com financiamento do ESRC - Economic and Social Research Council, Inglaterra (no. RES-062-23-1914). Contou também com recursos do CNPq, através de Bolsa de Produtividade em Pesquisa concedida a Santos. O material etnográfico sobre o qual este texto está baseado foi coletado por Michael Kent durante pesquisa realizada entre maio e dezembro de 2010. Entrevistas foram conduzidas com Maria Cátira Bortolini, Andrea Marrero e outros geneticistas envolvidos nos estudos genéticos sobre os Gaúchos. Somos particularmente agradecidos ao tempo concedido pelos pesquisadores. Gostaríamos também de agradecer a Peter Wade, Verlan Valle Gaspar Neto, Vivette Garcia Deister e Maria Fernando Olarte Sierra por suas valiosas contribuições para as reflexões desenvolvidas neste artigo. Kent agradece especialmente a Ruben Oliven e Claudia Fonseca pelas oportunidades de troca de ideias durante o trabalho de campo em Porto Alegre. Verônica Zembrzuski fez uma leitura de uma versão preliminar deste texto, a quem agradecemos os comentários. Rodrigo Ciconett Dornelles realizou a tradução deste texto, originalmente em inglês. Gostaríamos de agradecer ao jornal Zero Hora pela autorização para reproduzir a matéria "Os charruas vivem".

Horizontes Antropológicos, Porto Alegre, ano 18, n. 37, p. 341-372, jan./jun. 2012 
condições sociais e genéticas que possibilitaram o estabelecimento de tal continuidade, assim como a afirmação da especificidade genética dos Gaúchos. Finalmente, são explorados os impactos sociais dessa pesquisa, em particular as suas articulações com construções de uma identidade regional diferenciada.

Palavras-chave: Charrua, Gaúchos, genética, políticas de identidade.

Abstract: This paper aims to explore the articulation between genetic ancestry research and social constructions of ethnic identity in the state of Rio Grande do Sul. It will do so by analysing the social life of a research project conducted at the UFRGS that established genetic continuity between the contemporary Gaúcho population and the assumedly extinct indigenous Charrua. In the course of time, this idea of genetic continuity has taken on different incarnations, within varying contexts, and affirmed with differing levels of certainty. This paper will focus on the social and genetic conditions that have enabled the establishment of such continuity, as well as the affirmation of the genetic distinctiveness of the Gaúchos. Finally, it will explore the social impacts of this research, in particular its articulation with constructions of a differentiated regional identity.

Keywords: Charrua, Gaúchos, genetics, identity politics.

\section{Introdução}

"Os charruas vivem", afirmou o dramático título de uma matéria de página inteira publicada em agosto de 2003 no jornal Zero Hora, de Porto Alegre (Figura 1) (Werb, 2003). ${ }^{1}$ A notícia era particularmente marcante, pois muitos acreditavam que os Charrua, que nos tempos pré-coloniais eram o povo indígena dominante na região do Pampa do Rio Grande do Sul e no vizinho Uruguai, estavam extintos desde a primeira metade do século XIX. A matéria veio ilustrada com a imagem de um homem de olhar desafiador, vestido em pele de animal e com lança e boleadeira, além de um outro habilidosamente sobre um cavalo. Todas essas representações não se referiam, contudo, aos Charrua de uma pequena comunidade que vive atualmente na periferia de Porto Alegre.

1 Matérias sobre a pesquisa foram publicadas não somente no Rio Grande do Sul, como também em jornais de outras regiões do país, mostrando o interesse mais amplo pelo tema (ver Lopes, 2003; Zorzetto, 2007).

Horizontes Antropológicos, Porto Alegre, ano 18, n. 37, p. 341-372, jan./jun. 2012 


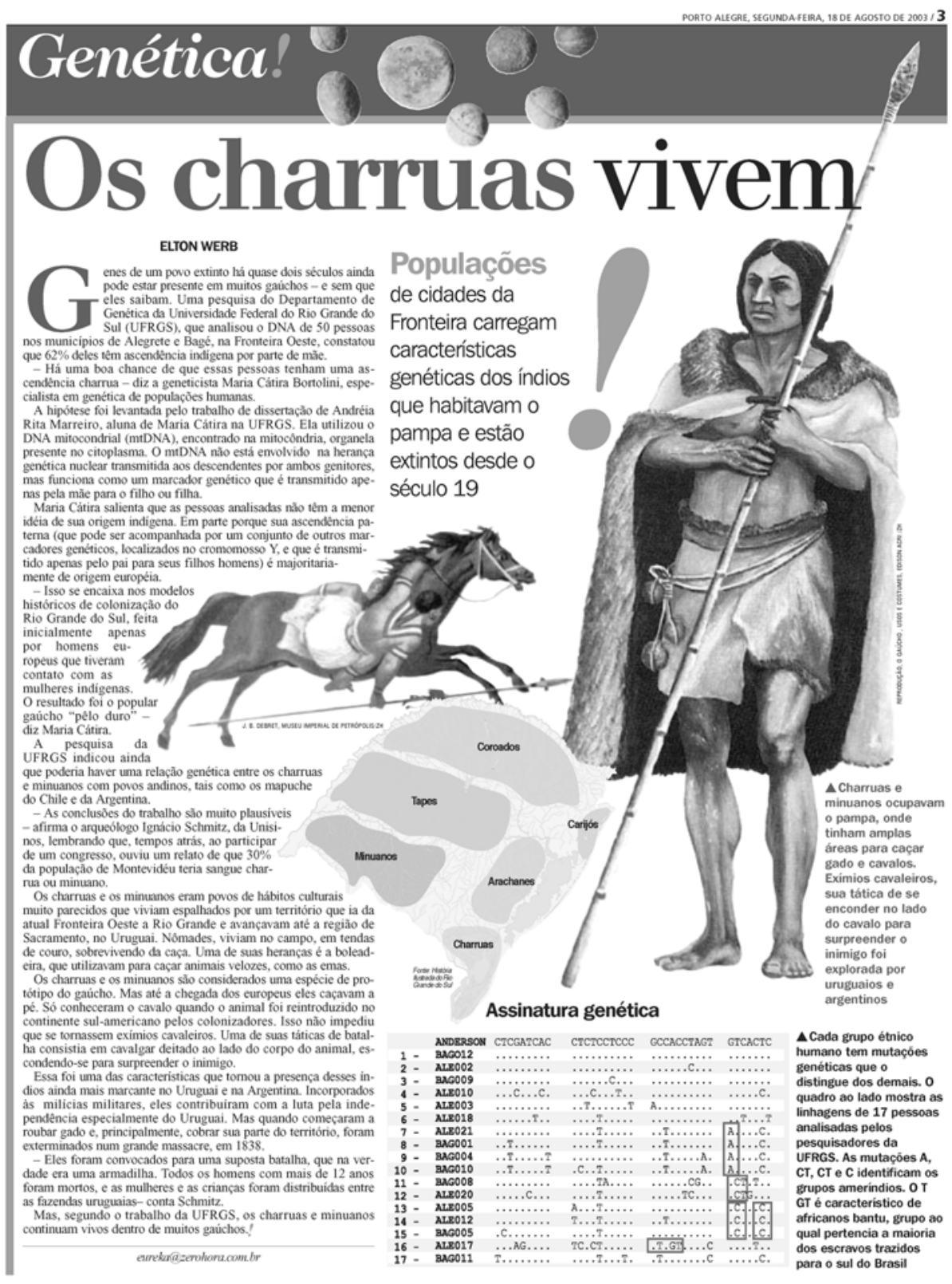

Figura 1. Matéria de Zero Hora (Werb, 2003).

Horizontes Antropológicos, Porto Alegre, ano 18, n. 37, p. 341-372, jan./jun. 2012 
Apelando a essa identidade étnica diferenciada, tal comunidade vem reivindicando junto ao Estado brasileiro, desde alguns anos, o direito a um território próprio. Mencionando que "cada grupo étnico humano tem mutações genéticas que o distingue dos demais", o foco da reportagem era a pesquisa genética coordenada pela professora Maria Cátira Bortolini, da Universidade Federal do Rio Grande do Sul (UFRGS). Logo na frase inicial da matéria de Zero Hora lia-se: "Genes de um povo extinto há quase dois séculos ainda podem estar presente em muitos gaúchos - e sem que eles saibam."

Como amplamente conhecido, "Gaúcho", além de ser o termo geralmente usado para se referir à população do Rio Grande do Sul, é também a designação do arquétipo social do homem do campo da região do Pampa e que se tornou uma identidade regional bastante distintiva e representativa do estado. ${ }^{2}$ A partir de 2001, Bortolini, sua então pós-graduanda Andrea Rita Marrero e outros pesquisadores iniciaram investigações sobre o perfil genético dos Gaúchos. Em suas análises, os geneticistas atribuíram ênfase particular na possibilidade da origem charrua de linhagens maternas identificadas na população que atualmente vive na região pampeana. Tendo entrado frequentemente em conflito com as populações coloniais, os Charrua foram derrotados pelo exército uruguaio em 1831, com a eliminação da maior parte da população. Quatro sobreviventes, incluindo o último chefe (Vaimacá Perú), chegaram a ser levados a Paris e exibidos como curiosidades exóticas, tendo morrido pouco tempo depois (Bracco, 2004; Houot, 2002). "Mas", como concluiu a matéria de Zero Hora, "segundo o trabalho da UFRGS, os charrua e os minuanos ${ }^{3}$ continuam vivos dentro de muitos gaúchos".

Foram vários anos de pesquisas e uma cuidadosa construção de argumentos antes que os geneticistas se sentissem suficientemente seguros para apresentar suas interpretações através de artigos em revistas acadêmicas. $\mathrm{Na}$ terceira e última publicação relativa a essa pesquisa, de 2007, afirmaram: "a herança materna Charrua talvez tenha sido mais importante [no Gaúcho contemporâneo] do que se supunha inicialmente", revelando "uma extraordinária

\footnotetext{
2 Ao longo deste texto, ao utilizarmos o termo "Gaúcho" (em maiúscula), estaremos nos referindo principalmente à população da região do Pampa. Outros termos e expressões, como "gaúchos" (em minúsculas) e "população gaúcha", serão empregados com referência à população do Rio Grande do Sul em geral.

3 O termo Charrua não se refere somente ao povo do mesmo nome, mas também é usado como um rótulo genérico para outras etnias que viviam na região do Pampa em tempos pré-coloniais, tais como os Minuano, Guenoa e Yaró.
}

Horizontes Antropológicos, Porto Alegre, ano 18, n. 37, p. 341-372, jan./jun. 2012 
continuidade genética no nível do DNA mitocondrial" (Marrero et al., 2007a, p. 169). Pode-se afirmar que a possibilidade de uma continuidade genética entre os extintos Charrua e os Gaúchos contemporâneos já estava presente como uma hipótese-chave no início da pesquisa. No entanto, como veremos neste trabalho, o argumento assumiu diferentes contornos, a depender de contextos específicos, tendo sido colocado com diferentes graus de certeza.

Do ponto de vista da pesquisa genética, o estabelecimento de uma continuidade se mostrou significativamente mais difícil pela assumida extinção, em época remota, dos Charrua. Tal como indicado por Bortolini em uma entrevista, "eu não tenho parâmetros [...] eu nunca vou saber como eram os Charrua porque eles não existem mais [...] não tenho o povo original para poder comparar". ${ }^{4}$ Como acessar diretamente as características genéticas dos Charrua não era possível, os pesquisadores tiveram que construir as ligações através do que Bortolini definiu como "inferências indiretas": uma multiplicidade de associações, exclusões e traduções que estabeleceram a continuidade mais como provável do que como definitiva. Nesse processo, os geneticistas lançaram mão de um extenso leque de repertórios para além da biologia, incluindo informações e interpretações das áreas da história e da arqueologia, além de entendimentos sociais acerca da identidade gaúcha.

Em geral, nas pesquisas em genética de populações humanas, inferências e comparações são elementos centrais da prática científica. Afirmações sobre a ancestralidade de determinados indivíduos e comunidades são estabelecidas em comparação com outras populações (Barnes; Dupré, 2008; CavalliSforza; Menozzi; Piazza, 1994; Pritchard et al., 2000). Dados antropológicos, arqueológicos, históricos e linguísticos, bem como o senso comum, são frequentemente acionados, influenciando os rumos das interpretações científicas. Articulações entre repertórios biológicos e sociais, portanto, não são incomuns nas pesquisas em genética de populações humanas (Kent, 2011; Maio; Santos, 2010; Montoya, 2007; Palmie, 2007; Santos; Maio, 2004; Wade, 2007). A propósito, tais articulações não são características exclusivas da genética,

\footnotetext{
4 As informações discutidas neste trabalho são oriundas de dois registros etnográficos complementares, quais sejam, entrevistas e observações durante o trabalho de campo e análises das publicações científicas. No caso dos dados derivados das publicações, as fontes são indicadas especificamente através de citações aos trabalhos divulgados nos periódicos científicos. Quando não forem indicadas referências específicas, as fontes são de entrevistas e observações.
}

Horizontes Antropológicos, Porto Alegre, ano 18, n. 37, p. 341-372, jan./jun. 2012 
mas se fazem presentes nas ciências naturais e nas ciências da vida em geral (cf. Jasanoff, 2004; Latour, 1993; Pálsson, 2007; Rabinow, 1996).

A pesquisa sobre o perfil genético dos Gaúchos, que os geneticistas apontam como parte do campo da "genética histórica" (Marrero et al., 2007a, p. 161), se insere em uma longa tradição de investigação sobre a questão da formação genética das populações brasileiras (cf. Maio; Santos, 2010; Santos; Salzano; Bortolini, 2002; Maio, 2004). Em muitos aspectos, o projeto e as práticas analisadas neste artigo podem ser considerados como representativos da pesquisa genética sobre ancestralidade de populações brasileiras de uma forma mais geral. Não obstante, os pontos aqui analisados levantam, de uma forma particularmente condensada, questões relevantes para se compreender, de uma perspectiva antropológica, a gênese e o desenvolvimento dessas investigações. Diante da presumida extinção biológica dos Charrua, que resultou na impossibilidade de se chegar aos parâmetros genéticos através do estudo de uma população viva, o uso dos saberes de fora do campo da genética teve mais destaque que o usual. Assim sendo, o estudo de caso, através do enfoque nos diferentes estágios da pesquisa, oferece uma oportunidade para explorar as múltiplas traduções e cadeias de articulações entre repertórios de ordem social e biológica (Latour, 1993, 2005).

Desse modo, o objetivo central deste artigo é, com foco em um conjunto de pesquisas sobre ancestralidade biológica, conduzir uma análise acerca das condições de possibilidade sociais e científicas envolvidas na iniciativa de "resgate" genético (ou se poderia dizer, até mesmo, "ressurreição", considerando a ênfase do artigo em Zero Hora) dos Charrua. Isso será feito por meio da análise da vida social da investigação, reconstruindo as fases do projeto de pesquisa desde sua hipótese inicial até sua finalização, incluindo as reverberações na mídia de que "os charruas vivem” na população gaúcha atual.

\section{A construção social da identidade gaúcha}

O Rio Grande do Sul é o estado mais meridional do Brasil. Faz fronteira, ao sul, com o Uruguai e, ao leste, com a Argentina. Na época colonial, os Guarani e Charrua eram as etnias indígenas mais numerosas que ocupavam o que é a atual área do estado. Nesse tempo, o controle sobre a região se alternou entre portugueses e espanhóis. Logo depois de o Brasil se tornar

Horizontes Antropológicos, Porto Alegre, ano 18, n. 37, p. 341-372, jan./jun. 2012 
independente de Portugal, em 1822, o Rio Grande do Sul travou uma guerra de independência contra o governo central, entre os anos de 1835 e 1845, que ficou conhecida como Revolução Farroupilha. Por influência dessa trajetória histórica, persiste no presente um forte sentimento de diferença da população do Rio Grande do Sul em relação ao restante do Brasil. Em larga medida, segundo Oliven (2006), a construção de uma identidade regional diferenciada se desenvolveu como resposta aos esforços de centralização realizados pelo governo federal e em contraste com a identidade nacional brasileira.

O termo "gaúcho" refere-se tanto à população do Rio Grande do Sul como a um "tipo" social específico originário do Pampa, na região de fronteira com Uruguai e Argentina. A região do Pampa, com suas fazendas de pecuária extensiva, foi o centro do poder econômico do estado antes da expansão da indústria e da acelerada urbanização ocorrida na primeira metade do século XX. A figura do Gaúcho arquetípico é tipicamente representada como a do homem do campo, ou seja, o trabalhador de fazendas, cujo vestuário inclui espora, bota, bombacha, pala e chapéu, além de ser apreciador de chimarrão e churrasco. Masculinidade agressiva e forte senso de independência são outras características associadas à imagem do Gaúcho. Esses atributos contrastam com aqueles da identidade nacional brasileira e, com o passar do tempo, os contornos identitários do Gaúcho se deslocaram, pelas mãos das elites do estado, para o centro da construção social da identidade regional. Ao longo desse processo, a imagem do Gaúcho tornou-se cada vez mais mítica, tomando proporções de ícone (Bornholdt, 2010; Oliven, 2006). Atualmente, a identidade gaúcha é celebrada de diversas formas, incluindo o Movimento Tradicionalista Gaúcho (MTG). Criado em 1966, tal movimento orgulha-se de ser o "maior movimento de cultura popular no mundo ocidental", com aproximadamente 1500 centros filiados e mais de 1,4 milhões de membros registrados (Oliven, 2006, p. 122-123).

Entre o final do século XIX e o início do XX, ocorreu uma migração de larga escala de europeus para o Rio Grande do Sul, especialmente de alemães e italianos. Nas construções contemporâneas da identidade gaúcha, branquitude e ascendência europeia são aspectos proeminentes. No presente, o argumento de serem predominantemente europeus é um dos principais utilizados pelos habitantes do Rio Grande do Sul para se diferenciarem do restante da 
população brasileira. Essa equivalência entre a população do estado, branquitude e ascendência europeia é também uma dimensão bastante presente nas pesquisas genéticas conduzidas na UFRGS, em especial em estudos de genética médica que utilizam amostras de pessoas consideradas "brancas" do estado como modelo para populações europeias (ver, por exemplo, Zembrzuski; Callegari-Jacques; Hutz, 2006). Na construção social da identidade regional, tanto as contribuições dos indígenas quanto dos negros para a formação da população do Rio Grande do Sul tendem a ser pouco enfatizadas, quando não ignoradas (Leite, 1996; Oliven, 2006). A possibilidade de que, na formação da população gaúcha, tenha ocorrido também miscigenação com indígenas é um tema que recebe pouca atenção não somente em estudos genéticos como também por uma parte significativa da historiografia sobre o Rio Grande do Sul. A esse respeito, o título de uma publicação é revelador: "a miscigenação que não houve" (Dacanal, 1980).

Apesar dessa ênfase limitada na miscigenação física/biológica, às populações indígenas - e aos Charrua em particular - são atribuídas influências na formação da população gaúcha do Pampa. Esta é frequentemente conceituada como resultando da fusão do colono europeu com os Charrua, deles tendo herdado atributos culturais, determinadas habilidades e certas características psicológicas. Em particular, tem destaque a habilidade charrua de cavalgar, seu senso de independência e o seu caráter belicoso - alguns dos elementos mais emblemáticos da identidade do Gaúcho (Becker, 2002; Oliven, 2006). Nessas construções sobre a participação indígena, praticamente não são feitas referências aos Guarani e aos Kaingang, que sobreviveram ao processo de colonização e no presente vivem, em sua maioria, em situação de extrema pobreza em diversas regiões do estado. Tal padrão ressoa com uma tendência mais geral no Brasil e na América Latina de glorificar populações indígenas extintas e pouco enfatizar as contribuições daquelas que são contemporâneas (De la Cadena, 2000; Monteiro, 1996). Nessa visão, há uma hierarquia de valores em jogo: a ferocidade, hipermasculinidade e independência atribuída aos Charrua, em particular em relação à sua recusa de se submeter aos invasores europeus, os faz ancestrais "mais dignos e desejáveis" que os Guarani e os Kaingang. No complexo processo de construção identitária, é a "permanência psicológica" dos Charrua na "alma" da população gaúcha que é enfatizada, ao invés da miscigenação física/biológica (Rosa 1957 apud Oliven, 2006, p. 195). 


\section{As origens do projeto de pesquisa}

A geneticista Maria Cátira Bortolini, que foi a principal pesquisadora do Projeto Gaúcho, se reconhece como descendente de alemães e italianos. Bióloga de formação, Bortolini estudou no Programa de Pós-Graduação de Genética e Biologia Molecular da UFRGS, em Porto Alegre, onde concluiu o doutorado em 1996. No ano seguinte se tornou professora do Departamento de Genética da UFRGS. Além da pesquisa sobre os Gaúchos, Bortolini tem coordenado diversas outras investigações, sobre temas como povoamento pré-histórico do continente americano, genética de populações negras e relação entre fenótipo e genótipo. ${ }^{5}$

O Projeto Gaúcho, iniciado em 2001, tem suas raízes em uma longa tradição de pesquisa sobre a ancestralidade genética de populações latino-americanas desenvolvida na UFRGS, iniciada por Francisco Mauro Salzano nos anos 1950 (Salzano, 1971; Salzano; Bortolini, 2002). O próprio Salzano participou de pesquisas sobre a diversidade genética em diversas regiões do Rio Grande do Sul, que indicaram que a região sudoeste, correspondente ao Pampa, apresentava as mais elevadas proporções de ascendência ameríndia (Dornelles et al., 1999). Se já havia estudos prévios, a pesquisa de Bortolini foi aquela que primeiro enfocou especificamente a figura do Gaúcho do Pampa.

Vale ressaltar que o Projeto Gaúcho insere-se em uma vertente mais ampla de pesquisas contemporâneas sobre os perfis genéticos da população brasileira, tanto em âmbito regional como nacional, que experimentaram significativa expansão a partir da década de 1990 (ver Pena, 2002; Salzano; Bortolini, 2002; Santos et al., 1999b). Além de Bortolini, outros pesquisadores-chave no Projeto Gaúcho foram Andrea Rita Marrero (que obteve seu título de mestrado em 2003 e de doutorado em 2006, ambos no âmbito do projeto) e Francisco Mauro Salzano, este último principalmente na condição de consultor. A lista completa dos geneticistas que participaram do projeto pode ser encontrada em Marrero et al. (2005; 2007a, 2007b).

Há uma série de fatores relevantes na origem do Projeto Gaúcho. De acordo com Bortolini, um dos principais interesses estava na possibilidade de

\footnotetext{
5 Sugere-se consultar o currículo Lattes de Bortolini disponível na internet para uma visão mais detalhada acerca de sua inserção em projetos de pesquisa e sua produção acadêmica (ver http://lattes.cnpq. br/9465728212459541).
} 
"resgatar" genomas de populações extintas, considerando a hipótese de que os Gaúchos do Pampa poderiam constituir um "reservatório" de linhagens genéticas charrua. Ou seja, um "genoma testemunho", que por sua condição de miscigenado teria o potencial de reconstruir a "história perdida" de populações indígenas extintas (Bortolini et al., 2004). Além da dimensão de pesquisa em si, Bortolini explicitou em entrevistas quanto ao considerável nível de envolvimento pessoal com o projeto. A geneticista declarou que via a pesquisa como uma "homenagem" ao último líder charrua, Vaimacá Perú. A forte identificação de Bortolini enquanto uma gaúcha também desempenhou um papel importante na escolha do tema do perfil genético regional: "Aí mostra o fato de eu ser gaúcha... um gaúcho ia se motivar para fazer... Porque eu tenho orgulho de ser gaúcha." Em uma entrevista em 2003, Bortolini apresentou a busca de linhagens charrua na população gaúcha como "uma possibilidade ímpar na busca do conhecimento sobre protagonistas de nossa própria história" (Genes dos gaúchos..., 2003). ${ }^{6}$

O desenvolvimento do Projeto Gaúcho também se associa ao interesse em questionar as frequentes associações no âmbito de pesquisas genéticas, bem como no imaginário popular, entre a população do Rio Grande do Sul, branquitude e ascendência europeia. As investigações de Bortolini têm enfatizado o alto nível de mistura genética das populações brasileiras, em especial de pessoas classificadas como pretas ou negras, a partir do qual a geneticista tem se posicionado em relação ao que coloca como tendências racialistas em curso na sociedade brasileira (Bortolini, 2005, 2009; Bortolini et al., 1997, 1999; Hunemeier et al., 2007; Pena; Bortolini 2004). Nesse âmbito, a figura do Gaúcho ganha contornos de particular importância. Para Bortolini, tal figura representa uma identidade social abrangente e que chega a ofuscar diferenciações subjacentes, em particular em termos de raça ou de cor da pele. Como ela afirmou: "Se alguém está vestido de bombacha, e alguém vê, vai falar 'olha lá um gaúcho', antes de dizer 'olha lá um negro'."

A literatura acadêmica de outras áreas do conhecimento, como história, sociologia, antropologia, entre outras, assim como o imaginário social sobre a identidade do Gaúcho, foram determinantes na concepção e nas direções

6 Essa noção de busca por conhecimento de "si" através da pesquisa sobre o "outro" não é incomum na área da genética de populações humanas (ver Cunningham, 1998; Reardon, 2005; Santos, 2002).

Horizontes Antropológicos, Porto Alegre, ano 18, n. 37, p. 341-372, jan./jun. 2012 
tomadas pela pesquisa genética. De acordo com Bortolini, foi a noção de continuidade cultural entre os Charrua e os Gaúchos, bem como os registros de elementos culturais compartilhados indicados na literatura antropológica e histórica, que desencadearam a hipótese de que poderia existir continuidade no plano genético. A pouca ênfase ou mesmo negação da possibilidade de contribuição biológica dos indígenas na constituição biológica da população do Rio Grande do Sul também teriam contribuído para o interesse em explorar questões de continuidade a partir de uma perspectiva genética. Portanto, a pesquisa genética, desde seus primórdios, esteve em diálogo com dimensões socioculturais mais amplas relacionadas à identidade gaúcha.

Como veremos adiante, o Projeto Gaúcho construiu a continuidade genética entre o Gaúcho contemporâneo e os Charrua através de um conjunto de passos conceituais. O primeiro deles foi diferenciar o Gaúcho do restante da população do Rio Grande do Sul, o que foi feito enfatizando-se a herança materna ameríndia predominante (ou seja, através do DNA mitocondrial ou mtDNA); o segundo foi excluir a possibilidade de que a herança ameríndia presente nos Gaúchos tivesse origem guarani ou kaingang; finalmente, o terceiro passo esteve relacionado ao estabelecimento de conexões entre os Gaúchos e os Charrua.

O Projeto Gaúcho resultou em três artigos científicos, que foram publicados em revistas científicas internacionais de ampla circulação. A primeira e a segunda publicações analisaram os perfis genéticos da população geral do Rio Grande do Sul (Marrero et al., 2005) e das populações indígenas guarani e kaingang (Marrero et al., 2007b), respectivamente. De acordo com Marrero, com esses trabalhos, "[...] a gente foi criando a referência, a base bibliográfica para publicar o [artigo] dos Gaúchos [...] A gente estava preparando [o caminho]... O ponto final era o grande artigo, o artigo dos Gaúchos com os Charruas". A terceira publicação, que estabeleceu a continuidade genética entre os Charrua e os Gaúchos (Marrero et. al., 2007a), apresentou de forma ampliada os objetivos, argumentos e principais achados do Projeto Gaúcho.

\section{Questões de pesquisa, métodos e amostras}

Segundo Bortolini, a principal questão não respondida pelos estudos sócio-históricos era se o processo de povoamento da região do Pampa teria ocorrido com ou sem miscigenação entre as populações indígenas e os 
colonizadores. Tal questão, que diz respeito à natureza das relações sociais entre os colonizadores e os Charrua durante o período colonial, foi, através do Projeto Gaúcho, abordada através de uma perspectiva genética. A formulação da questão central em termos de miscigenação foi um aspecto crucial, uma vez que a interação entre populações, o que pode ser expressar em mistura, é um tema primordial de interesse da genética de populações.

Outro passo conceitual importante foi o estabelecimento de paralelos entre continuidade sociocultural e genética. Entendimentos sociais acerca da presumida proximidade cultural entre os Charrua e os Gaúchos, expressa na forma de atributos, habilidades e traços característicos compartilhados, tiveram um papel central. A explicação de Marrero é particularmente ilustrativa acerca desse ponto:

A personalidade do Charrua, do pampeano em geral, é muito forte [...] é o próprio Gaúcho [...]. O Gaúcho herdou muita coisa dos Charrua: andar a cavalo, tomar o mate, comer o assado, churrasco. Então a gente pensou: esse componente ameríndio pampeano é muito forte culturalmente nos Gaúchos. Isso vem de algum lugar [...] Não é simplesmente uma coisa absorvida. [...] Essa herança cultural que a região do Pampa recebeu dos Minuano [...] eu acho que é a porta de entrada para permitir a miscigenação genética entre eles.

Segundo essa perspectiva, as dimensões genética e sociocultural do encontro interétnico se mostram em constante interação. Se, por um lado, as afinidades culturais podem facilitar o intercâmbio biológico, por outro a transmissão cultural é pouco provável sem que também aconteça "mistura". Nesse âmbito, a mescla de elementos culturais e genéticos se coloca como indissociável, o que permite a tradução de associações culturais entre os Gaúchos e os Charrua em conexões genéticas.

A metodologia empregada no Projeto Gaúcho envolveu a análise do DNA mitocondrial e do cromossomo Y, alocando-se as linhagens individuais em haplogrupos populacionais específicos e calculando-se as proporções relativas de contribuições ameríndias, europeias e africanas para os diversos conjuntos de amostras. A opção de se trabalhar simultaneamente com DNA mitocondrial e cromossomo $\mathrm{Y}$ requer que somente os homens possam ser incluídos como doadores do material genético a ser analisado (já que as mulheres não apresentam cromossomo $\mathrm{Y}$ ). 
Uma vez definidas a questão central e a abordagem metodológica, o passo seguinte foi estabelecer um painel de amostras de Gaúchos consideradas representativas. Um dos conjuntos analisados veio de coletas na região do Pampa, tido pelo geneticistas como "berço" do Gaúcho. Uma razão adicional para a escolha dessa região foi, de acordo com Bortolini, que "ali é a área de índios Charrúa; ali você poderia fazer esse resgate, porque ali não tinha outro índio". A opção por se coletar as amostras na região pampeana estabeleceu, então, uma primeira equivalência geográfica e continuidade histórica entre os Charrua e os Gaúchos do passado e do presente.

Um primeiro conjunto de amostras analisadas pelo projeto (30 no total) foi coletado na cidade de Bagé pelo geneticista inglês Steven Stuart. Segundo Marrero (2003, f. 45), as amostras "foram obtidas em um acampamento farroupilha durante as comemorações realizadas anualmente no mês de setembro, as quais buscam relembrar a epopeia dos farrapos e da República Riograndense". Foram incluídos indivíduos nascidos na região e cujos ancestrais eram também da região do Pampa.

Em Alegrete, selecionada por se localizar no centro da região do Pampa, foi realizada a coleta de um segundo conjunto de amostras (22 no total). Em uma entrevista, Marrero descreveu alguns detalhes da coleta. Em uma praça no centro da cidade, os pesquisadores, ao verem um homem com "aparência de gaúcho", inclusive em vestes tradicionais, dele se aproximavam, explicavam as razões da pesquisa e indagavam sobre a possibilidade de coleta de material biológico para fins de estudos de ancestralidade. Desse relato se depreende que o arquétipo social do Gaúcho, com seus sinais diacríticos específicos, informou parcialmente a seleção das amostras. Um critério seletivo adicional era que os indivíduos amostrados deveriam ter todos os seus avós nascidos na região do Pampa.

Também em Alegrete, dessa vez em um quartel militar no qual serviam sobretudo recrutas da região do Pampa, foi coletado um terceiro conjunto de amostras, mais numeroso (ver Marrero, 2006; Vargas et al., 2006). Uma vez que, por estarem com uniforme militar, os soldados não apresentavam atributos culturais explícitos associados ao arquétipo do Gaúcho, a aparência física tornou-se um importante critério na seleção. De acordo com Marrero, características fenotípicas, como pele morena e sinais de mistura com algum componente indígena, foram critérios distintivos. Conforme indicado em Vargas et al. (2006), um total de 103 soldados se voluntariaram para participar no 
estudo. Os locais de nascimento dos pais e avós foram registrados com a finalidade de estabelecer se os indivíduos tinham no Pampa as origens de seus ancestrais de pelo menos duas gerações.

Portanto, atributos culturais particulares de um Gaúcho arquetípico (em particular as vestimentas) e características físicas presumidas foram centrais no processo de seleção dos indivíduos amostrados. Ademais, incluir indivíduos cujos avós haviam nascido na região do Pampa reforçou a perspectiva da população Gaúcha como particularizada a um dado espaço geográfico. ${ }^{7}$

\section{A diferenciacão genética dos Gaúchos}

O primeiro passo no sentido de construir uma continuidade genética entre os Charrua e os Gaúchos foi de diferenciar este em relação ao restante da população do Rio Grande do Sul em geral. Ao mesmo tempo, foi enfatizada a proximidade dos Gaúchos com a população do Pampa uruguaio. Esse quadro emergiu a partir da constatação da significativa proporção de herança indígena materna nos Gaúchos (através do mtDNA), bem como pelo predomínio de herança paterna espanhola (através do cromossomo Y).

Esse passo foi importante por diversas razões. Segundo os entendimentos sociais e os estudos históricos, os Charrua são geralmente associados às regiões que estiveram sob influência colonial espanhola. Em contraste, segundo os geneticistas, a visão predominante sobre a formação da população do Rio Grande do Sul não enfatiza a inclusão dos Charrua (Marrero et al., 2007a, p. 161). Na construção de seu argumento, os geneticistas precisaram diferenciar os Gaúchos do Pampa tanto do brasileiro genérico quanto da população mais abrangente do Rio Grande do Sul. Segundo Marrero, "a primeira coisa que a gente fez foi isso: separamos. Existem culturalmente e geneticamente dois gaúchos, vamos dizer assim, que são completamente diferentes."

Para tanto, a pesquisa genética envolveu estabelecer as características genéticas de amostras de diferentes regiões do Rio Grande do Sul, usadas como um modelo para o estabelecimento da população "branca" genérica do estado, bem como de um conjunto amostral derivado de uma comunidade

7 Esses três conjuntos de amostras, quais sejam, as duas de Alegrete e a de Bagé, foram utilizados no artigo final do Projeto Gaúcho (Marrero et al., 2007a). 
de descendentes de imigrantes europeus que chegaram à região da Serra (Veranópolis) no final do século XIX e no início do XX (Marrero et al., 2005). ${ }^{8}$ O objetivo foi avaliar a heterogeneidade genética da população do Rio Grande do Sul (Marrero et al. 2005, p. 497). Além disso, ao enfatizar um perfil genômico predominantemente europeu na amostra da Serra, bem como a proporção significativa de DNA mitocondrial indígena na amostra geral do Rio Grande do Sul avaliada (36\%), esse artigo, além de apontar para importantes diferenças genéticas internas no Rio Grande do Sul, também diferenciou explicitamente a população do Rio Grande do Sul daquela do Brasil como um todo. Posteriormente, na terceira publicação do projeto (Marrero et al., 2007a), as amostras investigadas em Marrero et al. (2005) foram comparadas com aquelas coletadas no Pampa.

Os resultados da análise de DNA mitocondrial foram muito importantes no delineamento genético dos Gaúchos, em particular por apontar para os elevados níveis de contribuição indígena. A porcentagem de 52\% de haplogrupos de DNA mitocondrial de origem ameríndia levou os geneticistas a concluírem que os "Gaúchos contemporâneos constituem o mais importante reservatório de linhagens de DNA mitocondrial ameríndia no Brasil, fora da região Amazônica" (Marrero et al., 2007a, p. 168). Em termos comparativos, conforme indicado em Marrero et al. (2007a, p. 165), análises genéticas indicaram uma porcentagem de DNA mitocondrial ameríndio bastante inferior (11\%) para uma amostra composta de indivíduos de várias regiões do Rio Grande do Sul (excluindo Pampa) e de 22\% para uma amostra da região Sul do Brasil, esta última investigada por Alves-Silva et al. (2000). ${ }^{9}$

As análises sobre o cromossomo Y, apresentadas em Marrero et al. (2007a), também tiveram um importante papel na diferenciação dos Gaúchos do restante da população do Rio Grande do Sul. Além disso, tais análises associaram os Gaúchos com populações cuja ancestralidade é mais amplamente

8 Essas amostras haviam sido originalmente coletadas para fins de outras pesquisas em genética médica e forense, tendo sido também utilizadas no Projeto Gaúcho.

9 É possível que as magnitudes dessas diferenças tenham sido influenciadas por dois fatores. Primeiro, a presença de indivíduos não somente classificados como "brancos" na amostra de Gaúchos coletadas em Alegrete e Bagé, em contraste com uma composição unicamente de "brancos" nas amostras "Rio Grande do Sul - Other regions" e "Brazil - South" (ver Marrero et al. 2007a:165). Segundo, no caso das amostras "Rio Grande do Sul - Other regions", a maior parte dos indivíduos amostrados era originária de Veranópolis, uma cidade de colonização italiana da região da Serra, com menor proporção de indivíduos de outras regiões do Rio Grande do Sul (Marrero et al. 2007a:165).

Horizontes Antropológicos, Porto Alegre, ano 18, n. 37, p. 341-372, jan./jun. 2012 
reconhecida como charrua, como é o caso do Pampa uruguaio, originalmente de colonização espanhola. De acordo com Marrero, o Gaúcho típico da região do Pampa é uma "mistura de espanhol com Charrua". Os geneticistas estabeleceram uma associação no nível genético através da definição da herança genética paterna do Gaúcho como espanhola, ao invés de portuguesa, que é a mais comum no Brasil e no Rio Grande do Sul. Através do uso, por exemplo, de medidas de distância genética e de caracterização dos haplótipos individuais, chegaram à conclusão de que "os Gaúchos têm quatro vezes menos diferenciação com os espanhóis... em comparação com os portugueses" (Marrero et al. 2007a, p. 163). Esse passo foi crucial no estabelecimento da continuidade genética entre os Charrua e os Gaúchos, uma vez que inseriu esses últimos no cenário de uma mistura genérica, no Pampa, de espanhóis e Charrua. Além disso, por extensão, situou os Gaúchos como na esfera de influência cultural e genética dos Charrua.

\section{A exclusão dos Guarani e dos Kaingang}

Devido à ausência de parâmetros genéticos diretos sobre os Charrua, um segundo passo fundamental na construção da continuidade genética entre os Charrua e os Gaúchos foi excluir a possibilidade de que as linhagens ameríndias fossem oriundas de populações indígenas outras que não a charrua. Essa exclusão se deu de duas formas. A primeira foi através da ênfase de que a região do Pampa estava sob o exclusivo domínio dos Charrua no tempo da colonização. Isso foi feito, em particular, através do uso de mapas com informações arqueológicas. Tais mapas mostravam o território do Rio Grande do Sul como dividido em regiões de ocupação mutuamente excludentes pelos Charrua, Guarani e Kaingang, com a área do Pampa sob domínio dos primeiros (Marrero et al., 2007a, p. 161). A segunda forma foi excluindo os Guarani e os Kaingang, as mais numerosas etnias indígenas que vivem atualmente no Rio Grande do Sul, como possíveis colaboradores para o pool genético dos Gaúchos.

A publicação "Demographic and evolutionary trajectories of the Guaraní and Kaingang Natives of Brazil" (Marrero et al., 2007b) desempenhou um papel importante nessa construção ao apresentar as frequências dos principais haplogrupos ameríndios de DNA mitocondrial e o cromossomo Y. Na publicação final (Marrero et al., 2007a), essas frequências são comparadas com 
aquelas dos Gaúchos. Uma diferença particularmente marcante foi observada entre os Gaúchos (A, 30\%; B, 31\%; C, 30\%; D, 9\%) e os Guarani (A, 85\%; $\mathrm{B}, 0 \% ; \mathrm{C}, 9 \%$; $\mathrm{D}, 6 \%$ ), o que levou os geneticistas a concluírem que "ao se considerar a ancestralidade ameríndia através do DNA mitocondrial, não foram observadas conexões entre os Gaúchos e os Guarani” (Marrero et al., 2007a, p. 169). Os Kaingang foram excluídos como possíveis ancestrais genéticos dos Gaúchos através do uso de registros históricos e da análise de rotas de migração, que de acordo com os geneticistas não evidenciavam que os Kaingang já tivessem habitado a região do Pampa (Marrero et al., 2007a, p. 168-169).

Os geneticistas ofereceram uma razão de porquê os Charrua teriam sido mais propensos do que os Guarani a terem se miscigenado à população colonial. Isso se associaria a uma dimensão de gênero, com particular destaque nos 5\% de linhagens ameríndias nos cromossomos Y dos Gaúchos, a mais alta proporção encontrada em populações brasileiras, ultrapassando até a região amazônica (Marrero et al., 2007a, p. 163). Isso levou à explicação de que os homens charrua foram significativamente mais bem sucedidos em reproduzir-se com mulheres de origem europeia do que os homens de outros grupos indígenas, sendo os únicos a deixarem sua marca genética impressa nas populações brasileiras contemporâneas. Segundo Marrero, foi justamente a resistência do homem Charrua e seu caráter guerreiro (características que os distinguiriam de outras populações indígenas, segundo ela) que fizeram com que a miscigenação com as populações coloniais se tornasse possível. Tais atributos o tornaram objeto de desejo das mulheres não indígenas (incluindo as europeias) e de respeito por parte dos homens. Essa explicação encontra eco na mitificação dos Charrua anteriormente descrita. Além disso, oferece um cenário distinto daquele mais comum acerca dos padrões de miscigenação nas Américas, segundo o qual os homens europeus foram capazes de se impor frente às mulheres ameríndias e africanas, eclipsando a contribuição genética dos homens indígenas e africanos (Pena et al., 2009; Santos et al., 1999a).

\section{Conexões entre os Gaúchos e os Charrua}

As análises das frequências de haplogrupos de DNA mitocondrial não foram utilizadas somente para diferenciar os Gaúchos, mas também para estabelecer associações com um conjunto de amostras e de populações correspondentes que são mais facilmente relacionáveis aos Charrua. 
Em primeiro lugar, os geneticistas estabeleceram associações com a população do Uruguai. Pesquisas anteriores da geneticista Mónica Sans e colaboradores haviam revelado uma elevada proporção de DNA mitocondrial de origem ameríndia na população do país, o que foi atribuído à ancestralidade charrua (Bonilla et al., 2004). No último artigo do Projeto Gaúcho, os autores efetuaram uma comparação com uma amostra do Pampa uruguaio, de Tacuarembó, que "foi originalmente habitado por tribos indígenas, incluindo os Charrua" (Marrero et al., 2007a, p. 165). Tanto a proporção de DNA mitocondrial (62\%) de origem ameríndia como os padrões de distribuição entre os quatro haplogrupos (21/34/32/13) evidenciadas nas amostras analisadas indicaram semelhanças com o perfil genético da amostra de Gaúchos. Similaridades foram também notadas na distribuição dos haplogrupos dos Gaúchos com outras populações investigadas no Uruguai (Marrero et al., 2007a, p. 165).

Em segundo lugar, o componente ameríndio da amostra de Gaúchos mostrou-se associado ao perfil de populações indígenas da região do Cone Sul. Na introdução do artigo final da pesquisa, os geneticistas afirmaram que os dados arqueológicos apoiariam uma "conexão entre os Charrua e as populações aborígenes da Terra do Fogo e da Patagônia", assim como uma "provável continuidade cultural" entre os primeiros habitantes do Pampa e os Charrua nos tempos da colonização (Marrero et al. 2007a, p. 161). O artigo lista as frequências de haplogrupos de DNA mitocondrial de três grupos indígenas da Patagônia e de quatro da Terra do Fogo, com base na extração de DNA antigo (ou seja, obtido de material arqueológico). Em um gráfico de distância genética construído a partir de dados de sequenciamento de DNA mitocondrial, os Gaúchos aparecem próximos dessas populações, o que levou os autores a deduzir que há uma "relativa proximidade dos perfis de DNA mitocondrial entre elas" (Marrero et al., 2007a, p. 169). A similaridade deriva, sobretudo, da elevada presença do haplogrupo C nas amostras do Cone Sul. Assim, através de uma série de conexões no espaço e no tempo, os Gaúchos foram geneticamente vinculados a prováveis populações ancestrais dos Charrua e, por extensão, aos Charrua propriamente. Ao se estabelecer uma associação entre os Gaúchos e as populações indígenas que chegaram ao atual território do Rio Grande do Sul a partir do sul, também se operou uma diferenciação com relação aos Guarani e Kaingang, que teriam chegado à região vindos do norte.

Horizontes Antropológicos, Porto Alegre, ano 18, n. 37, p. 341-372, jan./jun. 2012 
Finalmente, em terceiro lugar, o artigo associa os Gaúchos ao "lendário chefe charrua" Vaimacá Perú. Capturado pelo exército uruguaio na batalha de Salsipuedes, que aconteceu em 1831, ele foi levado, com três outros Charrua, para Paris, onde foi exibido como curiosidade exótica. Vaimacá faleceu logo depois e seus restos mortais incorporados ao acervo do Museu de História Natural de Paris. Em 1998, seus restos foram repatriados para o Uruguai, onde foram depositados no Panteón Nacional, em Montevidéu. Antes desse segundo enterramento, a geneticista uruguaia Mónica Sans coletou amostras e conduziu análises genéticas, através das quais concluiu que o DNA mitocondrial de Vaimacá correspondia ao haplogrupo C (Sans et al., [s.d.]). Nas análises das amostras de Gaúchos, os geneticistas não observaram um pareamento direto com a linhagem detectada na amostra de Vaimacá. Contudo, devido à importância do haplogrupo $\mathrm{C}$ para diferenciar os Gaúchos dos Guarani, a presença desse haplogrupo no que era a única amostra seguramente Charrua contribuiu para afirmar a associação genética entre os Gaúchos e os Charrua (Marrero et al., 2007a, p. 168).

\section{A micropolítica da interpretação científica}

Os resultados das pesquisas acima discutidos não identificaram as linhagens ameríndias encontradas nas amostras dos Gaúchos como sendo diretamente charrua. Na seção "Resultados" do artigo final não é estabelecida uma associação entre os Gaúchos e os Charrua (Marrero et al., 2007a). Não obstante, tomadas em conjunto, estas "inferências indiretas" levaram os geneticistas a construir tal associação como provável. Na seção de discussão do artigo, afirmaram que "nossos resultados indicam que a herança materna charrua pode ter sido mais importante do que inicialmente sugerido" (Marrero et al., 2007a, p. 169). A linguagem utilizada no trabalho científico é cautelosa. Como explicou Marrero,

uma coisa que a gente sempre teve muita cautela é que nunca se poderia afirmar que [as linhagens] são charrua. E isso para um geneticista é muito difícil para lidar, [pois] você nunca termina uma questão. Mas nós tínhamos quase certeza que ali tinha Charrua. Acho que se colocássemos essas hipóteses, se fossemos em frente nisso, dificilmente a gente publicaria [o trabalho científico]. 
No entanto, na conclusão do artigo, observa-se um grau de certeza mais pronunciado, uma vez que se afirma que "os nossos dados revelaram que a conhecida continuidade cultural entre populações pré e pós-colombianas do Pampa foi também acompanhada de uma extraordinária continuidade genética no nível do DNA mitocondrial" (Marrero et al., 2007a, p. 169). Isso sugere que diferentes contextos, até mesmo no âmbito de um mesmo artigo, permitem expressar uma afirmação científica com diferentes níveis de certeza.

Bortolini recebeu diversos convites para realizar apresentações sobre o Projeto Gaúcho, em especial de universidades do próprio Rio Grande do Sul. Ela se sentiu mais à vontade para estabelecer a continuidade genética entre os Gaúchos e os Charrua nessas apresentações. Em uma aula para estudantes de pós-graduação na UFRGS, em outubro de 2010, por exemplo, afirmou que "parte daquelas linhagens indígenas que a gente não estava identificando como guarani, na verdade eram charrua [...] Então a gente conseguiu resgatar um pouco do genoma de um povo extinto." Em diálogos informais também havia maior espaço para o argumento da continuidade. Por ocasião de uma conversa sobre o Projeto Gaúcho que incluía, além de um de nós (Kent), Bortolini e uma outra geneticista, esta última comentou que considerava que as evidências apontando para os Charrua eram "muito indiretas". Bortolini respondeu: "Nesse caso eu estou muito convencida [...] eu tenho muita convicção de que é verdade. Eu só não posso provar de maneira categórica por falta de elementos."

Portanto, a depender do contexto, as afirmações sobre a conexão entre os Gaúchos e os Charrua podem variar da ausência de menção na seção de "Resultados" de publicações acadêmicas a afirmações mais explícitas sobre a sua "verdade" em ambientes mais informais, com diferentes graus de certeza no meio. Na construção de continuidade entre os Charrua e os Gaúchos, o dilema central que os geneticistas tiveram que lidar era com a "quase certeza", uma vez que não havia possibilidades técnicas disponíveis para oferecer a prova definitiva. A situação, que era passível de contestação, colocou os geneticistas em um campo de negociação sobre a validade de traduções entre os resultados específicos da pesquisa e afirmações mais gerais sobre a ancestralidade das amostras.

Essas micropolíticas da interpretação científica levantam uma questão crucial: por que os geneticistas investiram tanto esforço em estabelecer a conexão entre os Gaúchos e os Charrua? Uma primeira interpretação é que tal 
conexão estava diretamente relacionada a um dos objetivos-chave da pesquisa: recuperar linhagens de uma população extinta. Além disso, definir a contribuição indígena para a constituição genética dos gaúchos como charrua, ao invés de guarani, por exemplo, ecoa interpretações amplamente aceitas acerca da identidade regional no Rio Grande do Sul.

Finalmente, além de um esforço de pesquisa voltado para compreender a história de formação da população do Rio Grande do Sul especificamente, por certo o Projeto Gaúcho também se insere nos interesses de Bortolini acerca da "história genética" da população brasileira como um todo, incluído a genética de quilombos e de outras populações de origem africana (ver, entre outros, Bortolini et al., 1999). A questão dos elevados níveis de mestiçagem biológica da população brasileira e suas implicações sociopolíticas foi abordada em diversos trabalhos anteriores da geneticista (Bortolini, 2005, 2009; Pena; Bortolini, 2004). Para Bortolini, a importância da categoria social do Gaúcho se assenta no fato de que seria unificadora, transcendendo particularidades sociais e raciais. O perfil genético do Gaúcho, com altas proporções de ancestralidade ameríndia atribuída a etnias supostamente extintas, adquire um caráter particularmente inclusivo, uma vez que condensa importantes aspectos da própria história de colonização do Estado. Os resultados do Projeto Gaúcho servem ainda para desestabilizar a identificação étnico-racial da população do Rio Grande do Sul como eminentemente branca e europeia, ao mesmo tempo em que é mantido um caráter distintivo da população gaúcha em relação aos brasileiros em geral, uma vez que apresentaria uma mestiçagem particular.

\section{"Os charruas vivem": envolvimento social com o Projeto Gaúcho}

Ao ser incorporado nos debates públicos sobre pertencimento étnico-racial regional ou nacional, no âmbito dos movimentos sociais e da mídia, o conhecimento genético passa a interagir com uma infinidade de discursos preexistentes relativos a identidades individuais e coletivas. As interpretações sociais dos dados genéticos não raro resultam em alinhamentos entre os resultados em si e aspectos no plano de trajetórias pessoais, construção de identidades coletivas e dinâmicas de interesses políticos. A partir dessa interação entre fluxos de identidade social e de ancestralidade genética, pode haver a emergência do que Simpson (2000) denominou de "comunidades genéticas 
imaginadas", ou seja, padrões de identidade coletivas no âmbito de um grupo de pessoas baseados em características genéticas compartilhadas (Brodwin, 2002, 2005; Gaspar Neto; Santos, 2011; Kent, 2011; Nelson, 2008; Pálsson, 2007, 2008; Wade, 2007).

No caso da matéria do jornal Zero Hora, o jornalista foi muito além da afirmação de Bortolini sobre a continuidade entre os Charrua e os Gaúchos. Afirmando que os Charrua "vivem" dentro dos gaúchos, situou simbolicamente o resgate das linhagens de DNA mitocondrial no plano da ressurreição de um povo indígena supostamente extinto. Quando um de nós (Kent) perguntou a Bortolini o que pensava sobre o título da reportagem, ela respondeu, não sem alguma resignação: "Bem, isso é coisa de jornalista. Fiz todas as ressalvas durante a entrevista, mas aí deram este título sensacionalista." Complementou: "Eu acho legal [esse título]... particularmente, eu gostei, porque é verdade neste caso, especificamente [...] se olhar de uma maneira romântica não foram extintos."

Como vimos, apesar de Bortolini não se sentir suficientemente embasada para fazer uma afirmação à comunidade científica quanto à continuidade genética, a matéria jornalística se mostrou uma "tradução" de suas ideias em um contexto público com a qual ela se sentiu confortável. O jornalista, por não estar atrelado aos limites impostos pelo campo científico, teve muito mais liberdade para colocar a afirmação científica da provável continuidade genética entre os Charrua e os Gaúchos em uma linguagem de forte apelo: "os charruas vivem". A imagem dos Charrua utilizada na matéria foi aquela do guerreiro mitificado, feroz, considerada de mais fácil identificação junto ao público.

Uma das repercussões da matéria na imprensa foi que Bortolini passou a receber inúmeros pedidos para realizar testes genéticos de pessoas interessadas em reivindicar ancestralidade charrua: ${ }^{10}$

"Ah professora, eu sonhei que sou Charrua", "eu tenho alma charrua", "testa o meu DNA para ver se eu não sou Charrua", "porque eu tenho uma alma indomável". Tudo assim, coisas assim. [...] Nunca, nunca alguém chegou pra mim dizendo que achava que era Guarani. [É como se] Guarani não tivesse graça [...]

${ }_{10}$ Bortolini analisou o DNA mitocondrial de cinco dessas pessoas, com todos os resultados revelando ascendência matrilinear europeia.

Horizontes Antropológicos, Porto Alegre, ano 18, n. 37, p. 341-372, jan./jun. 2012 
não tem apelo hollywoodiano como tem esse Charrua [...] É que nem o meu marido quando eu fiz o DNA dele e deu uma linhagem que tinha nos Kaingang - ele disse: "Mas tinham que ser esses índios que nem usam pena na cabeça?"

Segundo Marrero, também entre seus colegas na UFRGS circularam comentários favoráveis pelo fato de que as evidências genéticas apontavam para uma proporção muito maior de ancestralidade charrua que guarani: " $\mathrm{E}$ uma pessoa disse assim: 'ainda bem porque os Guarani se dobraram para os colonizadores e os Charrua, não'. Então até isso é um motivo de orgulho. [Falaram também]: 'mas os índios do quais eu descendo são bravos, guerreiros, são lutadores [...] então isso era forte... morriam olhando nos olhos do seu carrasco'."

Do Pampa também vieram manifestações positivas em relação aos achados da pesquisa. De acordo com Marrero, muitas pessoas nessa região se reconhecem como miscigenadas, mas não se identificam como tendo descendendo dos Guarani, o que se expressou em uma das reações: "Eu sabia, eu sabia que essa minha cor era de pampeano." Ou seja, possuir uma cor mais escura devido à herança charrua foi indicado como socialmente mais aceitável se comparado à ancestralidade guarani ou negra.

Os resultados da pesquisa também tiveram repercussões nos movimentos nacionalistas gaúchos. Foram divulgados, por exemplo, em uma página eletrônica dedicada a celebrar a identidade regional, juntamente com afirmações de orgulho de ser parte do povo do Rio Grande do Sul e de que a "essência" do gaúcho "perdura" (Bagé - a mais gaúcha..., 2007). É possível que a aceitabilidade social da pesquisa pelos movimentos esteja associada, sobretudo, às possibilidades de se estabelecer uma diferença com a população brasileira mais geral.

As lideranças do pequeno grupo de pessoas que atualmente busca reconhecimento como Charrua também manifestaram interesse pelos resultados da pesquisa genética. Tal movimento, que buscou contato com Bortolini em diferentes momentos, estava reivindicando junto ao governo o reconhecimento de um território. Contudo, ao invés de solicitar a realização de testes genéticos, pediram que ela endossasse publicamente a reivindicação por eles apresentada de identidade charrua. Ou seja, esperavam obter apoio dos geneticistas para essa solicitação, amplamente contestada pelos representantes do Estado e por outros agentes do campo político, sob o argumento de que os 
Charrua estariam extintos. Após Bortolini se recusar diversas vezes, argumentando que a ciência não oferecia os meios para substanciar tal assertiva, eles desistiram. Ainda que o apoio não tenha vindo conforme esperado, tal como a cacique charrua Acuabé comentou para um de nós (Kent) por ocasião de uma visita à sua comunidade na região metropolitana de Porto Alegre, a pesquisa genética ajudou a dar respaldo ao pleito de reconhecimento oficial do grupo como Charrua. Isso teria contribuído para uma maior aceitabilidade da ideia de que os Charrua persistem até o presente (ver, para ter uma comparação, o caso dos uros do Peru analisado por Kent, 2011).

Portanto, há uma complexa série de fatores implicados no envolvimento e, em larga medida, na aceitação dos resultados da pesquisa genética sobre os Gaúchos pelo público em geral. A convergência dos achados genéticos com as interpretações da identidade gaúcha desempenhou um papel importante. Ao mesmo tempo em que os geneticistas se propuseram a buscar pelos Charrua no genoma dos gaúchos contemporâneos, havia uma elevada predisposição do público gaúcho quanto a aceitar essa associação. A perspectiva de que "os charruas vivem" encontrou ampla aceitabilidade social não somente pelo fato da valorização mítica dos Charrua pela sociedade, como também por deslocar para um segundo plano os Guarani como os ancestrais dos gaúchos. Além disso, os padrões de aceitabilidade estiveram associados a contextos políticos particulares, como nos casos do movimento nacionalista gaúcho e de etnogênese Charrua.

\section{Considerações finais}

A vida social do Projeto Gaúcho revela as fortes articulações entre repertórios sociais e biológicos na prática cotidiana da pesquisa genética. Nas várias etapas da investigação houve uma constante interação entre ideias e práticas genéticas, de um lado, e acionamentos da literatura arqueológica, antropológica e histórica, bem como do senso comum sobre a identidade do Gaúcho, de outro lado. Os argumentos dos geneticistas acerca da constituição genética dos Gaúchos basearam-se sobretudo na análise do DNA mitocondrial e do cromossomo Y. Contudo, os termos específicos por eles empregados eram fortemente influenciados por ideias sociais e históricas preexistentes sobre a identidade dos Gaúchos do Pampa e da população do Rio Grande do Sul, bem como pelas relações sociais e simbólicas que essa identidade condensa. Foi

Horizontes Antropológicos, Porto Alegre, ano 18, n. 37, p. 341-372, jan./jun. 2012 
o papel central que os supostamente extintos Charrua ocupam no imaginário gaúcho que permitiu Bortolini levantar a hipótese da continuidade genética entre eles desde o princípio. No decorrer dos anos, os pesquisadores criaram as condições, de uma perspectiva da genética, para o estabelecimento de tal continuidade através de um esforço sustentado na construção de inferências, associações e exclusões. No outro extremo da trajetória do projeto, a preferência entre muitos gaúchos pelos Charrua em detrimento dos ancestrais Guarani foi decisivo para que a pesquisa fosse, de um ponto de vista social, aceitável por um público mais amplo. Isso acabou criando as condições para a tradução da conclusão genética de que "as amostras de homens da região do Pampa revelam uma alta proporção de haplogrupo C no seu DNA mitocondrial" em sua encarnação social de que "os charruas vivem". A presente análise da trajetória do Projeto Gaúcho reafirma argumentos acerca do caráter "biossocial" e "híbrido" das práticas e categorias científicas, bem como a impossibilidade de dissociar os "domínios" social e biológico (Jasanoff, 2004; Latour, 1993; Pálsson, 2007; Rabinow, 1996; Reardon, 2005).

Em muitos aspectos, ao longo da pesquisa, os geneticistas reiteraram interpretações sociais convencionais da identidade do Gaúcho e da população do Rio Grande do Sul. Eles localizaram a autêntica genética do Gaúcho na região do Pampa. Eles também ajudaram a enfatizar a ideia do Gaúcho como hipermasculino, assim como contribuíram para seu status mítico ao atribuir a ele uma origem heroica em um povo indígena guerreiro. Além disso, os dados genéticos proveram apoio científico para a ideia de que a população gaúcha apresenta diferenças em relação à população brasileira em geral.

Não obstante, de outro modo, a pesquisa também reconfigurou significativamente a questão da identidade da população gaúcha. Em primeiro lugar, injetou repertórios genéticos nos debates públicos travados, resultando em uma biologização da questão identitária. A fusão da identidade social e da ancestralidade genética por pessoas fora do campo científico acabou contribuindo para a emergência de uma "comunidade genética imaginada". No processo, o caráter híbrido do Gaúcho mesmo foi acentuado, na medida em que as características sociais e genéticas tornaram-se altamente associadas. A fusão adicional nas construções sociais da identidade regional do Gaúcho do Pampa com a população do Rio Grande do Sul como um todo significa que afirmações sobre a constituição genética do Gaúcho do Pampa talvez se projete mais amplamente sobre toda a população do estado.

Horizontes Antropológicos, Porto Alegre, ano 18, n. 37, p. 341-372, jan./jun. 2012 
Além disso, a pesquisa enfatizou a contribuição física dos indígenas nas construções da identidade gaúcha. Isso ocorreu ao prover respaldo para a existência de altos níveis de miscigenação entre colonizadores e populações indígenas, contra as interpretações convencionais que descartavam a possibilidade de tal processo. Isto acabou convertendo os indígenas em ancestrais socialmente aceitáveis - não mais um outro radical, mas um familiar, através da sua incorporação nos corpos da população gaúcha. Entretanto, não foram os povos indígenas em geral que foram incorporados na "comunidade genética imaginada" da população gaúcha - mas sim um povo específico, os Charrua, cuja contribuição se encontraria "diluída" no Gaúcho, que é interpretado como um mestiço. Assim como na construção social da identidade gaúcha, na pesquisa genética também foram estabelecidas vinculações com um povo historicamente distante, supostamente extinto e glorificado, ao invés de com populações indígenas que sobreviveram até o presente, como os Guarani ou Kaingang. Se, por um lado, o objetivo explícito de Bortolini era resgatar linhagens genéticas ameríndias extintas, por outro, o seu envolvimento pessoal com a pesquisa sugere uma preocupação para além da evidenciação de atributos biológicos supostamente perdidos no passado. Os desdobramentos foram de várias outras ordens. Em primeiro lugar, a pesquisa ajudou a tirar os próprios Charrua do esquecimento, ainda que os colocando de volta à cena através de uma outra população. Em segundo lugar, resgatou o que Bortolini vê como o caráter inclusivo da identidade gaúcha, que é constantemente minado pela tendência de se enfatizar, para a população do Rio Grande do Sul, uma ancestralidade genética quase que exclusivamente europeia, minimizando-se a origens africanas e indígenas.

Para as populações indígenas atuais do Rio Grande do Sul, as consequências sociais dessa pesquisa são, em potencial, tanto positivas quanto negativas. Por um lado, através da legitimidade científica, potencialmente se aumentou a aceitação social quanto a se ter uma ascendência indígena na população do Rio Grande do Sul. Além disso, para a comunidade contemporânea dos Charrua, a noção de que "permanecem" até os dias de hoje teve um efeito de empoderamento em sua luta pelo reconhecimento oficial e seus direitos territoriais. Por outro lado, essa ideia de uma continuidade genética dos Charrua na população gaúcha também pode servir para relativizar a sua extinção e, assim, diluir a responsabilidade pelo genocídio do qual as populações indígenas têm sido vítimas no Rio Grande do Sul. No caso dos Guarani e dos Kaingang,

Horizontes Antropológicos, Porto Alegre, ano 18, n. 37, p. 341-372, jan./jun. 2012 
a sua marginalização da sociedade contemporânea passou a se coadunar com sua exclusão da comunidade genética imaginada do gaúcho.

Finalmente, a pesquisa e o seu impacto social revelam uma dinâmica de interação entre as formas com que os Gaúchos e os Charrua são imaginados e refletidos. Enquanto os supostos extintos Charrua ressurgem através do Gaúcho contemporâneo, este é imaginado, reafirmado e reconfigurado através do Charrua. Portanto, a reconstrução do passado é inextricavelmente conectada à reconfiguração do presente. No processo, os geneticistas não só contribuíram para a mitificação continuada da identidade do Gaúcho. Eles também, tal como o título do artigo de Zero Hora sugere, literalmente reavivaram o mito charrua.

\section{Referências}

ALVES-SILVA, J. et al. The ancestry of Brazilian mtDNA lineages. American Journal of Human Genetics, v. 67, p. 444-461, 2000.

BAGÉ-AMAIS GAÚCHA das cidades - notícias. Bagé Além da Fronteira, 15 dez. 2007. Disponível em: <http://bagealemfronteira.blogspot.com/2007/12/ bag-bag_15.html>. Acesso em: 2 maio 2011.

BARNES, B.; DUPRÉ, J. Genomes and what to make of them. Chicago: University of Chicago Press, 2008.

BECKER, I. I. B. Os índios Charrua e Minuano na antiga banda oriental do Uruguai. São Leopoldo: Editora Unisinos, 2002.

BONILLA, C. et al. Substantial native American female contribution to the population of Tacuarembo, Uruguay, reveals past episodes of sex-biased gene flow. American Journal of Human Biology, v. 16, p. 289-297, 2004.

BORNHOLDT, L. C. What is a Gaúcho? Intersections between state, identities and domination in Southern Brazil. (Con)textos, n. 4, p. 23-41, 2010.

BORTOLINI, M. C. A genética e a peritagem racialista. Horizontes Antropológicos, ano 11, n. 23, p. 262-263, 2005. 
BORTOLINI, M. C. Comentário acerca do artigo "Color, race, and genomic Ancestry in Brazil: dialogues between anthropology and genetics" de R. V. Santos et. al. Current Anthropology, v. 50, p. 805, 2009.

BORTOLINI, M. C. et al. Evolutionary and anthropological implications of mitochondrial DNA variation in African Brazilian populations. Human Biology, v. 69, p. 141-159, 1997.

BORTOLINI, M. C. et al. African-derived South American populations: a history of symmetrical and asymmetrical matings according to sex revealed by bi- and uni-parental genetic markers. American Journal of Human Biology, v. 11, p. 551-563, 1999.

BORTOLINI, M. C. et al. Ribeiro's typology, genomes, and Spanish colonialism, as viewed from Gran Canaria and Colombia. Genetics and Molecular Biology, v. 27, p. 1-8, 2004.

BRACCO, D. Charrúas, guenoas y guaraníes: interacción y destrucción: indígenas en el Río de la Plata. Montevideo: Linardi y Risso, 2004.

BRODWIN, P. Genetics, identity, and the anthropology of essentialism. Anthropological Quarterly, v. 75, n. 2, p. 323-330, 2002.

BRODWIN, P. "Bioethics in action" and human population genetics research. Culture, Medicine and Psychiatry, v. 29, n. 2, p. 145-178, 2005.

CAVAlli-SFORZA, L. L.; MENOZZI, P.; PIAZZA, A. The history and geography of human genes. Princeton: Princeton University Press, 1994.

CUNNINGHAM, H. Colonial encounters in postcolonial contexts: patenting indigenous DNA and the Human Genome Diversity Project. Critique of Anthropology, v. 18, p. 205-233, 1998.

DACANAL, J. H. A miscigenação que não houve. In: DACANAL, J. H.; GONZAGA, S. (Org.). RS: cultura e ideologia. Porto Alegre: Mercado Aberto, 1980. p. 25-33.

DE LA CADENA, M. Indigenous mestizos: the politics of race and culture in Cuzco, Peru, 1919-1991. Durham: Duke University Press, 2000. 
DORNELLES, C. L. E. A. et al. Genetics, surnames, grandparents' nationalities, and ethnic admixture in Southern Brazil: Do the patterns of variation coincide? Genetics and Molecular Biology, v. 22, p. 151-161, 1999.

GASPAR NETO, V. V.; SANTOS, R. V. Biorrevelações: testes de ancestralidade genética em perspectiva antropológica comparada. Horizontes Antropológicos, ano 17, n. 35, p. 227-255, 2011.

GENES DOS GAÚCHOS para deduzir a história genética da América e a evolução de sua ocupação nativa. Canal Ciência, 26 out. 2003. Disponível em: <http://www.canalciencia.ibict.br/pesquisa/0162-Genes-dos-gauchos-ea-historia-genetica-das-americas.html>. Acesso em: 16 out. 2010.

HOUOT, A. Un cacique Charrúa en París. Montevideo: Editorial Costa Atlantica, 2002.

HUNEMEIER, T. et al. Niger-Congo speaking populations and the formation of the Brazilian gene pool: mtDNA and Y-chromosome data. American Journal of Physical Anthropology, v. 133, p. 854-867, 2007.

JASANOFF, S. (Org.). States of knowledge: the co-production of science and social order. London: Routledge, 2004.

KENT, M. A importância de ser uro: movimentos indígenas, políticas de identidade e pesquisa genética nos Andes Peruanos. Horizontes Antropológicos, ano 17, n. 35, p. 297-324, 2011.

LATOUR, B. We have never been modern. Cambridge: Harvard University Press, 1993.

LATOUR, B. Reassembling the social: an introduction to actor-networktheory. Oxford: Oxford University Press, 2005.

LEITE, I. B. Negros no sul do Brasil: invisibilidade e territorialidade. Florianópolis: Letras Contemporâneas, 1996.

LOPES, R. J. Gaúchos carregam DNA de índios extintos. Folha de S. Paulo, São Paulo, p. A14-A15, 12 ago. 2003. 
MAIO, M. C.; SANTOS, R. V. (Org.). Raça como questão: história, ciência e identidades no Brasil. Rio de Janeiro: Editora Fiocruz, 2010.

MARRERO, A. R. Os gaúchos: sua história evolutiva revelada a partir de marcadores genéticos. Dissertação (Mestrado em Genética e Biologia Molecular)-Instituto de Biociências, Universidade Federal do Rio Grande do Sul, Porto Alegre, 2003.

MARRERO, A. R. História genética dos gaúchos - dinâmica populacional do sul do Brasil. Tese (Doutorado em Genética e Biologia Molecular)-Instituto de Biociências, Universidade Federal do Rio Grande do Sul, Porto Alegre, 2006.

MARRERO, A. R. et al. Heterogeneity of the genome ancestry of individuals classified as White in the state of Rio Grande do Sul, Brazil. American Journal of Human Biology, v. 17, p. 496-506, 2005.

MARRERO, A. R. et al. Pre- and post-Columbian gene and cultural continuity: the case of the Gaucho from southern Brazil. Human Heredity, v. 64, p. 160-171, 2007a.

MARRERO, A. R. et al. Demographic and evolutionary trajectories of the Guarani and Kaingang natives of Brazil. American Journal of Physical Anthropology, v. 132, p. 301-310, 2007b.

MONTEIRO, J. M. As 'raças' indígenas no pensamento brasileiro do Império. In: SANTOS, R. V.; MAIO, M. C. (Org.). Raça, ciência e sociedade. Rio de Janeiro: Editora Fiocruz; CCBB, 1996. p. 15-22.

MONTOYA, M. J. Bioethnic conscription: genes, race, and Mexicana/o ethnicity in ciabetes research. Cultural Anthropology, v. 22, p. 94-128, 2007.

NELSON, A. The factness of diaspora: the social sources of genetic genealogy. In: KOENIG, B. A.; LEE, S. S.-J.; RICHARDSON, S. S. (Org.). Revisiting race in a genomic age. New Brunswick: Rutgers University Press, 2008. p. $253-268$.

OLIVEN, R. G. A parte e o todo: a diversidade cultural no Brasil-nação. Petrópolis: Editora Vozes, 2006. 
PALMIE, S. Genomics, divination, "racecraft". American Ethnologist, v. 34, p. 205-222, 2007.

PÁLSSON, G. Anthropology and the new genetics. Cambridge: Cambridge University Press, 2007.

PÁLSSON, G. Genomic anthropology: coming in from the cold? Current Anthropology, v. 49, p. 545-568, 2008.

PENA, S. D. J. (Org.) Homo brasilis: aspectos genéticos, linguísticos, históricos e socioantropológicos da formação do povo brasileiro. Ribeirão Preto: Funpec, 2002.

PENA, S. D. J.; BORTOLINI, M. C. Pode a genética definir quem deve se beneficiar das cotas universitárias e demais ações afirmativas? Estudos Avançados, v. 18, p. 31-50, 2004.

PENA, S. D. J. et al. DNA tests probe the genomic ancestry of Brazilians. Brazilian Journal of Medical and Biological Research, v. 42, p. 870-992, 2009.

PRITCHARD, J. K.; STEPHENS, M.; DONNELLY, P. Inference of population structure using multilocus genotype data. Genetics, v. 155, p. 945-959, 2000.

RABINOW, P. Essays on the anthropology of reason. Princeton: Princeton University Press, 1996.

REARDON, J. Race to the finish: identity and governance in an age of genomics. Princeton: Princeton University Press, 2005.

SALZANO, F. M. (Org.). The ongoing evolution of Latin American populations. Springfield: Thomas, 1971.

SALZANO, F. M.; BORTOLINI, M. C. The evolution and genetics of Latin American populations. Cambridge, NY: Cambridge University Press, 2002.

SANS, M. et al. The "last Charrúa Indian" (Uruguay): analysis of the remains of Chief Vaimaca Perú. [s.d.]. Disponível em: $<$ http://precedings.nature.com/ documents/4415/version/1/files/npre20104415-1.pdf>. Acesso em: 10.jul. 2011. 
SANTOS, R. V. Indigenous peoples, postcolonial contexts and genomic research in the late 20th century: A view from Amazonia (1960-2000). Critique of Anthropology, v. 22, p. 81-104, 2002.

SANTOS, R. V.; MAIO, M. C. Race, genomics, identities and politics in contemporary Brazil. Critique of Anthropology, v. 24, p. 347-378, 2004.

SANTOS, S. E. B. et al. Differential contribution of indigenous men and women to the formation of an urban population in the Amazon region as revealed by mtDNA and Y-DNA. American Journal of Physical Anthropology, v. 109, p. 175-180, 1999a.

SANTOS, S. E. B. et al. The Amazonian microcosm. Ciência; Cultura, v. 51, p. 181-190, 1999b.

SIMPSON, B. Imagined genetic communities: Ethnicity and essentialism in the twenty-first century. Anthropology Today, v. 16, n. 3, p. 3-6, 2000.

VARGAS, A. E. et al. Frequency of CCR5 $\triangle 32$ in Brazilian populations. Brazilian Journal of Medical and Biological Research, v. 39, p. 321-325, 2006.

WADE, P. Race, ethnicity and nation: perspectives from kinship and genetics. New York: Berghahn Books, 2007.

WERB, E. Os charruas vivem. Zero Hora, Porto Alegre, 18 ago. 2003. Caderno Eureka! p. 3.

ZEMBRZUSKI, V. M.; CALLEGARI-JACQUES, S. M.; HUTZ, M. H. Application of an African Ancestry Index as a genomic control approach in a Brazilian population Annals of Human Genetics, v. 70, p. 822-828, 2006.

ZORZETTO, R. O DNA dos pampas. Pesquisa Fapesp, n. 134, 2007. 